如く他の地方にも相當に得らる〉所より見れば此の置格の大なると云ふ事 は二次的のもので標本となつた烏は何か極て良い條件の本に育つた点とも 見る事が出來る。

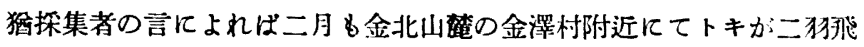
で居るのを見た。土地の人の話では其の附近で蕃殖する川である。又波高 の途中の海ではウ、カモメ(種不明)、ウミス、メ、アジサシ(種不明)等を 見たと云ふ事である。

\title{
On the Specimens of Korean Birds, collected by Mr. Hyojiro Orii.
}

By

\author{
Marquis Y. Yamashina.
}

Mr. Hyojiro Orii stayed in Korea (including the Quelpart Is.) for one year following April, 1929, and was engaged in the collection of birds, collecting 1940 specimens which belong to 41 families and 27 ? forms and some eggs. This collection is one of the most perfect ever brought from Korea. We have gotten three new subspecies among this collection. Besides, we have been able to add twenty-six species to the list of Korean birds (six of them also to the Japanese list). I offer my hearty thanks to him in appreciation of his services.

The itinerary of his collecting trip is as follows. (See the attuched map.)

He started from Tokyo in the last decade of March, 19:9.

From April 2nd, 1929, to June 4th, 1929, he sojourned at Riugampo, Heian-hokudo, chiefly collecting birds passing there in spring.

From June 11th, 1929, to July 18th, 1929, he sojourned at ('hosen, Kogendo, engaged in the collection of birds in the forests around IIt. Kongo. He collected a new subspecies of Pigmy Woodpecker during this period. 


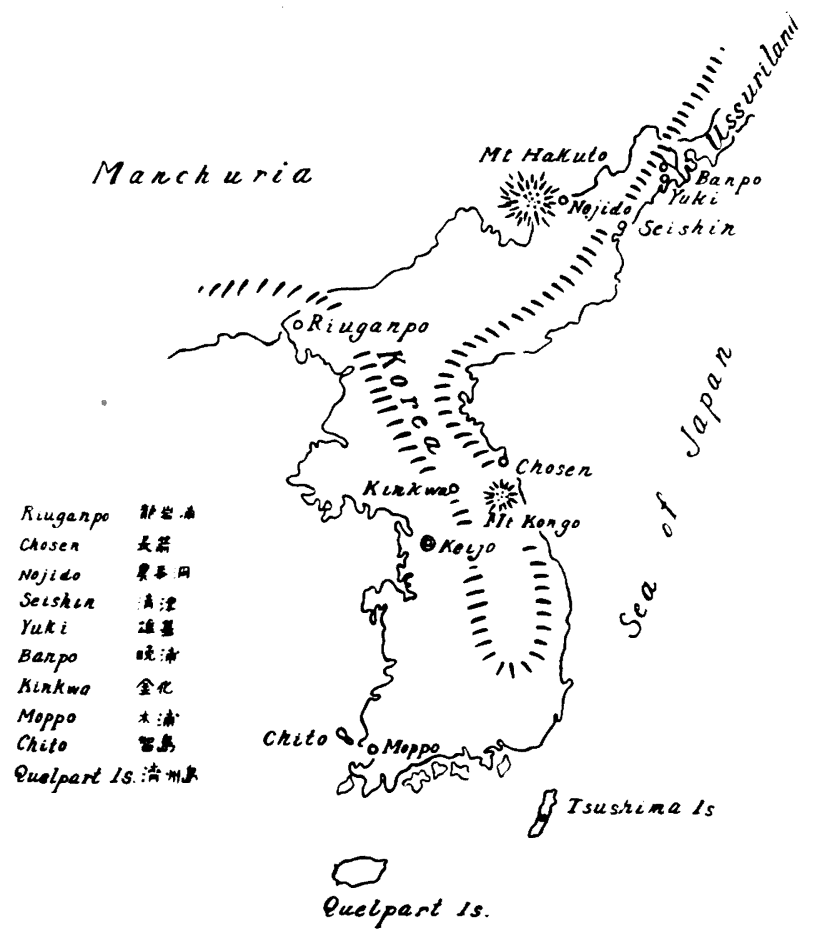

Fig. 29. Korean Peninsula.

From July 23rd, 1929, to September 6th, 1929 he sojourned at Nojido, Kankyo-hokudo, engaged in the collection of birds in the whole neighbourhood of Mt. Hakuto, He collected new subspecies of Three-toed Worlywerer and Lesser spottel Woodpecker (see the "Tori" No. 29), and in addition, a great number of birds which have some relations to ones in the Ussuri region, and illustrated the fact that Fauna in Kankyo-hokulo differ from those in the other parts of Korea.

After leaving Nojido on Sept. 6th. 1929 , he made a collection of some 
birds at Sanchō on his way, and then went to Seishin by way of Mozan, and farther northward to Yuki.

From September 12th, 1929, to November 21st, 1929, he sojourned at Bampo, Kankyo-hokudo, engaged in the collection of birds passing there in autumn. Jankowski's Bunting was collected during this period.

From November 25th, 1929, to December 6th, 1929, he occupied himself in the collection of birds at Kinkwa, Kogendo.

From the 7 th of December, 1929 to the 7 th of March, 1930, he sojourned at Moppo, Zenra-nando. He went to Chito several times to collect birds.

On March 8th, 1930, he crossed over the Quelpart Is., staying there till March 31st, 1930, collecting birds.

He returned to Tokyo in the first decade of April, 1930.

About some of the specimens collected about this time, I have already described at the "Tori" No. 2. . No. 29 and No. 30 . And now again, I have given all the specimens, including them, in the table $I$ have pade, giving some explanations where I think, it is necessary to do so.

\section{Family CORVIDÆ. 科}

1. Corvus corone corone Linnaeus. ハシポソガラス

$$
\begin{aligned}
\text { Synonym: } & \text { C. c. interpositus Laubmann. } \\
& \text { C. c. takahashii Momiyama \& Ishii. }
\end{aligned}
$$

2 ơ of ads. 10.-11. IV. 1929. Riuganpo.

1 of ad., 1 \&d. 3.-21. X. 1929. Banpo.

2 oै oे ads., $4 q q$ ads. 6. I.-25. II. 1930. Moppo.

The results of measurement of $5 \delta \delta$ ads. and $5 q q$ ads. above mentioned are as follows:

Wing $\delta \delta$ ads. $312-345$, $q q$ ads. 302-328.

Tail of of ads. 172-200, $q$ ads. 166-213.

Culm. $\delta \delta$ ads. 49-54, $q q$ ads. 48-52.5.

The results of measurement above mentioned coincide with the description of C. c. corone in the "Practical Handbook of British Birds" by Mr. Witherby, wing of 318-345, $7.310-325$. And the results of measure- 
ment of a great number of specimens of Hokkaido, Hondo and Kiusiu are as follows:

Wing of 311-347. \& :34!1-?+1!).

Thus, those in IIskkijilı. Hondo and Kiusiu are undistiguishable from those in Europe. Sis the method used by Dr. Hartert and Dr. Laubmann to classify $C$. corone into the western and the eastern form is wrong. Those in sixhalin have the measurement, wing 12 of of ads. 330-367, 7 $\uparrow q$ ads. 324-336 mm. and are of a larger size than C. corone corone. They belong to $C$. c. orirntalis Eversmann and ('. corone saghalense Kumagai is its synonym.

2. Corrus coronoides mandshuricus Buturlin.

$$
\text { テウセンハシブトガラス }
$$

Synonym: C. c. quelpartis Momiyama.

1 ơ ad. 22. VIII. 192!) Nojidō.

$1 \subsetneq \mathrm{imm} .3$. X. 1929. Banpo.

$1 \%$ ad. 2s. XI. 1929. Kinkwa.

$4 \delta \delta$ ads., 1 ad., 1 unsexed ad. 17.-30. III. 1930. Quelpart Is.

Those in the Quelpart Is. have a little longer bills than those in Korea, but the difference is not great. The results of measurement of $C$. coronoides in Korea and the Quelpart I. are as follows:

\begin{tabular}{|c|c|c|}
\hline 09 & $\begin{array}{l}\text { Wing } \\
\text { anti-its }\end{array}$ & $\begin{array}{l}\text { Ex. c. } \\
50.5-61\end{array}$ \\
\hline ơ $q$ als. & & \\
\hline
\end{tabular}

3. Corvu frugilegus pastinator Gould. ミヤマガラス

1 б̊ ju. 21. X. 192!. Banpo.

万o $\delta$ ads... $3 q q$ ads. 2. I.-26. II. 1930, 2roppo.

$1 \%$ ad. 13. IIJ. 1930. Quelpart 1.

4. Corvus dauricus dauricus Pallas. コクマルガラス

1 fo ad. 21. X. 1!!:!. Banpo.

3 of of ads., $7 q q$ ads. 2.) XII. 1929-1. III. 1930. Moppo.

5. Pica pica sericea Gould. カササギ

Synonym: Pi a varia japonica Schlegel.

$2 \delta \delta$ ads. 19. IV.-17. V. 1929 . Riuganpo. 
$1 \delta$ ad., $3 \nmid q$ ads. 2s. ViI.-12. ViII. 1929. Nojidō.

2 of of ads., 6 $q$ ads. 24. IX.-23. X. 1929. Banpo.

$4 \delta \delta$ ads.. $5 q q$ ads. 17. I.-27. II. 1930. Muppo.

According to the recent investigation of the specimens preserved in the collections of Takatsukasa, Kuroda and Yamashina, there is no distinction among the specimens of Formosa. Korea and Kiusiu, neither in measurement nor in coloring.

6. Cyanopica cyanus interposita Hartert. コマラナカ

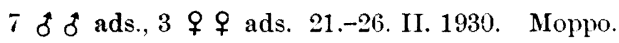

7. Garrulus glandarius taczanowskii Lönnberg. カラフトミヤマカケス Synonym: G. brandti okai Momiyama.

- 1 ơ ad., 1 q ad.. 2 jurs. 9. VIII.-3. JX. 1929. Nojidō.

G. glandarius of Korea in many specimens are almost undistinguishable from G. g. taczanowskii of Saghalin. G. I. pallidi rons of Hokkaido, on the contrary, can be easily distinguished from G. g. taczanowskii of Saghalin. It is unable to determine whether G. g. taczanowskii are distinguishable from G. g. brandti or not, as there have never been found the specimens of the Altai region.

Family STURNIDA. 椋鳥科

8. Spodiopsar cineraceus (Temminck). ムクドリ

3 of $\delta$ ads., $3 q q$ ads. 11. IV.-28. V. 1929. Riuganpo.

$1 \delta$ ad. 28. VII. 1929. Nojidō.

9. Sturnia sturnina (Pallas). シベリヤムクドリ

6 ठै $\delta$ ads.. $\neq q q$ ads. 18.-27. V. 1929. Riuganpo.

Family ORIOLIDE. 黄鳥科

10. Oriolus chinensis diffusus Sharpe. カウライウグヒス

Synonym: O. i. orllroxanthus Oberholser.

O. chinensis swinhoii Momiyama \& Ishii.

3 of $\delta$ ads., 2 $q$ ads. 11.-23. V. 1929. Riuganpo.

Taking many specimens, there is no distinction between those of Formosa and those of Korea neither in measurement nor in coloring.

Family FRINGILLID)无。徍 科

11. Coccothraustes coccothraustes verticalis T. \& B. 
カラフトシ メ

$2 \delta$ of ads., $1 \&$ ad. 27. X.-12. XI. 1929. Banpo.

$3 \% q$ ads. 25. XII. 1929-27. I. 1930. Mrnpo.

Those which live in Korea in winter belong to this subspecies. There is one more specimen beside those above mentioned.

1 of juv. 2s. VII. 1929. Noijido.

This specimen is one wbich has just left its nest. so its subspecific name can not be assertained. But, I have provisionally treated it as belonging to this subspecies.

12. Coccothraustes coccothraustes japonicus T. \& $S$ シ \

$1 \%$ ad. 17. III. 1930. Quelpart Is.

13. Eophona migratoria migratoria Hartert. コイカル

6 of $\delta$ ads., $5 q q$ ads. 9.-20. V. 1929 . Riuganpo.

$2 q \%$ ads. 24. II. 1930. Moppo.

14. Chloris sinica ussuriensis Hartert. テウセンカハラヒワ

$6 \delta \delta$ ads. $4 q q$ ads., 1 juv. (27. V.) 4. IV.-29. V. 1929. Riuganpo.

$1 q$ ad., 2 juvs. 15. VI.-13. VII. 1929 . Chōsen.

5 of $\delta$ ads. 25.-26. XI. 1929. Kinkwa.

$2 \delta$ of ads., $1 q$ ad. 7.-27. I. 1930. Moppo.

C. s. ussuriensis is a common resident in Korea.

15. Chloris sinica minor (T.\&\&) コカハラヒワ

synunym: C.s. affinis Momiyama.

$+\delta \delta$ als. 1 o ad. 14.-30. III. 1930. Quelpart I.

Chloris sinica which is a resident in the Quelpart $\mathrm{I}$. is given the name of Chloris sinicu affinis, but it is undistinguishable from C. s. minor of Hondo.

16. Carduelis spinus (Linnaeus). $\checkmark$ ヒ

3 of $\delta$ ads.. $2 q q$ ads. 22. X.-11. XI. 1929. Banpo.

$2 \delta \delta$ ads., $3 q \%$ ads. 17. I.-23. II. 1930. Moppo.

17. Carduelis linaria linaria (Linnaeus). ベニヒワ

1 juv. 17. XI. 1929. Banpu.

Abunt this specimen. I have described in the "Tori" Vol. VI. p. 257, that it belongs to $C$. hornemanni exilipes in accordance with the classifica- 
tion of Dr. Hartert, but, following the classification of Dr. F. Solomonsen, it belongs to the subspecies above mentioned.

18. Uragus sibiricus ussuriensis Buturlin. ヨナガベニマシコ

1 ơ ad. 12. VIII. 1929. Nojidō.

1 ơ ad. 27. X. 1929. Banpo.

1 \& ad. 2. III. 1930. Moppo.

The specimens above mentioned show the special feature of ussuriensis with the following measurement:

Wing of of 69, 68.5, \& 65 . Tail of o $71,73, \uparrow 69$.

19. Pyrrhula pyrrhula kamtschatica Taczanowski. ベニバラウン $1 \delta$ ad. 12. XI. 1929. Banpo.

(See the "Tori" Vol. VI. p. 25i.)

20. Pyrrhula pyrrhula griseiventris Lafresnaye. ウ ン

3 of $\delta$ ads., $1 \%$ ad. 28. X.-9. XI. 1929. Banpo.

$1 \delta$ ad., 4 $\$$ ads. 24. II.-2. III. 1930. Moppo.

21. Pyrrhula cassini Baird. ハイイロウン

$q$ ad. 6. XI. 1929. Banpo.

(See "Tori" Vol. VI. p. 257.)

22. Erythrina rosea (Pallas). オホマシロ

2 of $\delta$ imms., 1 q ad. 27. X. 1929. Banpo.

23. Loxia curvirostra japonica Ridgway. イスカ

$1 \delta$ ad., $3 q \%$ ads. 24. II. 1930. Moppo.

It has long been believed that there live both $L$. c. japonica and $L . c$. caucasica in Japan. But it is wrong, because the difference of size which has hitherto been regarded as the main point of distinction between them is but a variation within one and the same subspecies. This variation is wing of $\delta$ 92-102, $q$ o 87-97. Thus, there is no difference between this variation and the variation of Europian L. c. curcirostra, wing of $\delta$ 95100 , $q 91-95$. It is, however, an unquestionable fact that those in Japan have a deeper and brighter color, so far as the plumage of adult male are concerned, than those in Europe, and only from this point, they are distinguishable from $L$. c. curvirostra. L. c. caucasica is a synonym of L. c. japonica, I believe. 
24. Fringilla montifringilla Linnaeus. $>\vdash$ リ

$6 \delta$ of ads. $+q q$ ads. 4.-17. 11.1929 . Riuganpo.

1 o ad. 2!. I. 1!130. Moppo.

$1 \delta$ ad. 30. III. 1930. Quelpart I.

25. Leucosticte arctoa brunneinucha (Brandt). ハギマシュ

$2 \delta \delta$ ads., 2 $q$ ads. I. XI. 1929. Banpo.

26. Passer montanus saturatus Stejneger. スズメ

1 of ad.. 2 $q$ ads. 19--21. III. 1930. Quelpart I.

27. Passer montanus dybowskii Domaniewski. テウセンスズメ

$2 \delta \delta$ ads., $2 q q$ ads. 4. IV.-4. VI. 1929. Riuganpo.

$2 \delta \delta$ ads., $1 q$ ad. 20.-24. IV. 1929. Chösen.

$2 \delta$ fै ads. 22. VIII. 1929. Nojidō.

3 of $\delta$ ads., 1 ad. 16.-29. X. 1929. Banpo.

$2 \delta$ of ads. $1 \%$ ad. 20 . XII. 1929. Moppo.

28. Passer rutilaus rutilaus (Temminck). ニウナイスズメ

Synonym: P.r.parvirostris Momiyama.

$5 \delta$ of ads., $3 q q$ ads. 13.-2i. VI. 1929. Chisen.

$1 \delta$ ad. 26. III. 1930. Quelpart I.

There is no distinction between those in Japan (Hondo) and those in the Quelpart Is.

29. Emberiza rutila Pallas. シマノジュ

$7 \delta \delta$ ads., 2 $q$ ads. 10. V.-4. VI. 1929. Riuganpo.

30. Emberiza aureola Pallas. シマアラシ

$7 \delta$ ods. $3 q q$ ads. 30. IV.-16. V. 1929. Riuganpo.

31. Embcriza elegans elegans Temminck. ミヤマホホジロ

Synonym: E. e. ticehursti Sushikin.

3 d $\delta$ ads., $7 q q$ ads. 3.-13. IV. 1929. Riuganpo.

1 d ad. 30. VI. 1!2?!). ('hösen.

$1 \delta$ ad., 3 juvs. 27. VII.-21. VIII. 1929 . Nojirlō.

7 of ads., 1 ad. 15.-21. X. 192!. Banpo.

$1 \delta$ ad. 19. I. 1930. Mol'o.

1 के ad. 10. III. 1930. Quelpart I.

Those which pass the nothern part of Korea in spring and autumn 
(the so-called ticehursti) and those which breed in Korea are both undistiguishable from which breed in Hondo (that is. E. e. rlegans).

32. Emberiza spodocephala extremi-orientis Shulpin. カラア ジ

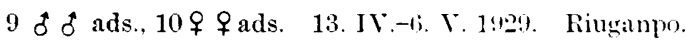

1 juv. 2. VIII. 1 !29. Nojidō.

1 o ad.. 6 $q$ ads., 2 imms. 19. IX.-1s. X. 192!. Banpo.

Twenty-nine specimens above mentioned all show the special feature of $E$. s. extremi-orientis, with a deep yellow in their throats and hreasts. Sometimes. E. s. spodocephala which have not been found in the collection of this time are collected in Korea. (There are some specimens of them in the collection of Takatsukasa!)

33. Emberiza cioides weigoldi Jacobi. ジベリアホホジロ i) $\delta$ of ads.. $2 q q$ ads. 7.-10. IV. 19⿻9. Riuganpo.

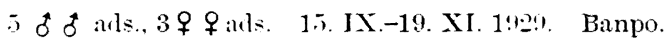

The reults of measurement of the above-mentioned 15 specimens are as folluws:

10 d \& ads. Wing $7+-8.2$. Tail $7: 3-41$.

$5 q q$ ads. Wing $i 2-7.5$. Tail $6 !-i s$.

E. c. weigoldi breed in the most northern part of Korea. and in winter they migrate southward to the middle part (to the neighbourhood of Keijo). Those which breed in the neighbourhood of (hosen (in the northern part of Kigrendō) belong not to this subspecies but to next one.

34. Emberiza cioile castaneiceps More. テウセンホホジロ Sinonym: E. c. tyoosenica Momiyama.

3 of of ads. 14.-15. VI. 1929. Clusen.

$1 \&$ ad. 6. I. 198?!. Mroum.

The result of measurement of the above-mentioned specimens are ats follows:

Wing of $\delta$ i

Tail of of $72-7 \pi$. $q$ i2.

Mr. Momiyama has given the name, E. c. tyoosenica to them, but there is no difference between them and $E$. c. castaneiceps which are 
natives of the eastern part of China, neither in measurement nor in coloration.

35. Emberiza cioides ijimae Stejneger. イイジマホホジロ

$6 \delta \delta$ ads., $3 q$ ads. 10-30. III. 1930. Quelpart Is.

The result of measurement of the nine specimens above mentioned are as follows:

Wing of $\delta$ 73-7s, + \% 71-7;

Tail of of $69-75$, $q$ \% $68-69$

Those which live in the Dagelet I., the Quelpart I., Tsushima I. and the Iki I. belong to this subspecies. Those in Kiusiu also have hitherto been regarded as belonging to it. But that is not the case, but they are typical E. c. ciopsis.

36. Emberiza jankowskii Taczanowski. コマホホジロ

3 of ads., $3 q q$ ads. 15. IX.-25. X. 1929. Banpo.

They are the first specimens collected in Korea. (See the "Tori" Vol. VI, p. 258.)

37. Emberiza fucata fucata Pallas. ホホアカ

Synonym: E.f. laubmanni Stachanow.

I of $\delta$ ads., 1 \& ad. 17. IV.-6. V. 1929. Riuganpo.

1 ơ ad. 13. VI. 1929. Chōsen.

$1 \delta$ ad. 23. II. 1930. Moppo.

$1 \delta$ ad. 13. III. 1930. Quelpart I.

As the result of investigating a great number of specimens of the same season, it has become known that there is no distinction betreen those which pass the northern part of Korea (E. f. fucata) and those which breed in Hondo.

38. Emberiza rustica Pallas. カシラタカ

Synonym: E.r. latifuscia Portenko.

$5 \delta \delta$ ads., $2 q$ \&ads. 2.-27. X. 1929. Banpo.

2 of $\delta$ ads., 1 ad. 25.-26. XI. 1929. Kinkwa.

1 of ad. 2. I. 1930. Moppo.

39. Emberiza pusilla Pallas. コホホアカ 
$3 \delta \delta$ ads., $1 \delta$ ? ad., $3 q q$ ads. 2.S. IV.-(;. V. 1929. Riuganpo.

40. Emberiza chrysophrys Pallas. キマンホホジロ

$2 \delta$ ads. 2. V. 1929. Riuganpo.

41. Emberiza tristrami Swinhoe. シロハラホホジロ

$7 \delta \delta$ ads., $5 q$ q ads. ㄴ. IV.-1. V. 1929. Riuganpo

42. Emberiza yessoensis continentalis Witherby.

$$
\text { テウセンコジュリン }
$$

1 jur. 1 q ad., 1 unsexed ad. 15.-2ti. X. 1!!e!!. Banpu.

$2 \delta$ ठ ads.. 1 ad. 2- 2 . XII. 1929. Moppo.

E. $y$. eontinentalis is easily distinguishable from the other subspecies.

43. Emberiza pallasi pallasi (Cabanis). シベリアジュリン

$1 \delta$ ad., 6 $q$ ads., $3 q$ imms. $2($ i. XI.-1. XII. 1929. Kinkwa.

$3 \delta$ of ads.. $3 q$ q ads., 1 imm. 24. XII. 1929-6. I. 1930. Moppo.

44. Calcarius lapponicus coloratus Ridgway. ツメナガホホジロ

$1 \%$ ad. 4. IV. 1909. Riuganpo.

$3 \delta$ \& ads., 1 o imm. $6 q q$ ads. 13. XII. 1929-6. I. 1930. Moppo. Family ALAUDIDE. 雲准科

45. Calandrella brachydactyla dukhunensis (sykes).

$$
\text { カラフトコヒパリ }
$$

$1 \delta$ ad. 17. IV. 1929. Riuganpo.

This is the first specimen collected in Korea (see the "Tori" Vol. VI. p. 169).

46. Galerida cristata coreensis Taczanowski. カンムリヒパリ

s of $\delta$ ads.. $3 q$ ads. 7.-27. IV. 1929. Riuganpo.

$1 \delta$ ad. T. I. 1930 . Yoppo.

47. Alauda arvensis pekinensis Swinhoe. オホヒバリ

2 of $\delta$ ads.. 3 $q$ ads. 13. XII. 1929. Moppo.

$A$ few of this subspecies also pass the winter in Korea.

45. Alauda arvensis lönnbergi Hachisuka. カラフトチウヒバリ

$3 \delta \delta$ ads., $t q q$ ads. 5.-20. X. 1929. Banpo.

$2 \delta$ of ads., 1 o ad. 13. XII. 1929. Moppo.

1 unsexed ad. 14. III. 1930. Quelpart Is.

Many of this subspecies pass Korea in spring and autumn, and those 
which pass the winter there are not so rare.

49. Alauda arvensis intermedia s'winhoe. ウチヒバリ

1 f ad., $3 q$ ads. 4.-1S. IV. 1929. Riuganpo.

11 ơ $\delta$ ads., $3 q q$ ads. 14. VI.-15, VII. 1929. Chōsen.

$1 \delta$ ad., 2 juvs., 1 unsexed ad. 30. VII.-15. VIII. 1929. Nojidō.

$6 \delta \delta$ ads., 5 $q$ ads., $1 q$ imm. 14. IX.; 9. XI. 1929. Banpo.

$2 \delta$ of ads. 2.-23. I. 1930. Moppo.

Those which breed in Korea all belong to this subspecies. In winter most of them migrate away southward and a few remain in Korea. Therefore, in winter three subspecies, that is, pekinensis, lönnbergi and intermedia, live together in Korea.

50. Alauda arvensis japonica T. \& $\ . \quad と \quad ハ \quad リ$

Synonym: A. a. quelpartae Nomiyama.

2 of of ads. 21.-30. III. 1930. Quelpart I.

A. arvensis in the Quelpart $\mathrm{I}$. is undistinguishable from those in Japan.

\section{Family NOTACILLIDE. 鶄领 科}

51. Anthus richardi richardi Vieillot. マミジロタヒハリ

5 of $\delta$ ads., 1 unsexed ad. 4.-12. V. 1929. Riuganpo.

The result of measurement is as follows:

Wing 90-93.5. Ex. c. 14.5-16.

Claw of hind-toe 16.5-18.

52. Anthus hodgsoni berezowskii Sarudny. ピンズイ

$8 \delta$ fads., $3 q q$ als. 29. IV.-11. V. 1929 . Riuganpo.

$1 \%$ ad. 9. X. 1929. Banpo.

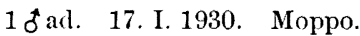

53. Anthus gustavi gustavi Swinhoe. セジロタヒバリ

6 of of ads., 1 ad. 29. IV.-3. V. 1929. Riuganpo.

5 of of ads. 1.-11. X. 1929. Banpo.

The length of wing of the above-mentioned 12 specimens are as follows :

$11 \delta$ of ads. 75-87, 1 ad. 77.

54. Anthus gustavi menzbieri Shulpin. コセジロタヒパリ 
3 of of ads., 1 \& ? ad. 29. IV.-3. V. 1929. Riuganpo.

These \pm specimens coincide with the description of Anthus $g$. menzbieri. The length of wing of the above mentioned specimens is as follows:

4 ads. $76-x-2$

5.万. Anrhus rufogularis Brehm. ムネアカタヒパリ

$s \delta \delta$ ads., $3 q q$ ads. 2s. IV.-4. V. 1929. Riuganpo.

$2 \delta$ o ads. 4.-s. X. 1929. Banpo.

$1 \subsetneq$ ad. 11. III. 1930. Quelpart I.

\%i. Anthus spinoletta blakistoni Swinhoe. サメイロタヒパリ

1 of ad. 1. XII. 1929. Kinkwa.

This is the first specimen collected in Korea. ("Tori " Vol. VI, p. 256.) According to Mr. La Touche, many of this subspecies live in the northern China in winter, so it is no cause for wonder that it was collected in Korea.

万. Anthus spinoletta japonicus T. \& S. タヒパリ

Synonym: A. borealis Hesse.

$1 \delta$ ad., $5 q q$ ads. 15. IV.-3. V. 1929. Riuganpo.

$2 \delta \delta$ ads., $9 \% q$ ads. 26. IX.-29. X. 1929. Banpo.

1 of ad. 19. II. 1930. Moppo.

I have already described in the "Journal für Ornithlogie" 1931, p. .04, that Anthus borealis resembles closely Anthus s. japonicus. And, as the result of the further investigation of a great number of specimens, it has become known that both are quite undistinguishable from each other.

5s. Motacilla flava macronyx (Stresemann).

キタッメナガセキレイ

8 of $\delta$ ads., 2 $q$ ads. T.-16. IV. 1929. Riuganpo.

$1 \delta$ ad. 20. IX. 1929. Banpo.

These specimens are typical macronyx. There is one more specimen, d ad. 17. IX. 1929, Banpo. It has almost undiscernible grey patches in its supercilium. It is an intermediate specimen between $M . f$. simillima and M.f.macronyx, I believe.

59. Motacilla flava simillima Hartert. マミジロツメナガセキレイ 
2 of of ads., 1 o ad. 17.-18. IX. 1929. Banpo.

These specimens are typical simillima. There is one more specimen, of ad., 8. V. 1929, Riuganpo. Its supercilicum is not white. but grey. It is also an intermediate specimen between macronyi and simillima, I believe.

60. Motacilla flava taivanus (Swinhoe). ツメナガセキレイ

1 of ad., 1 \& ad. 2. V. 1929 . Riuganpo.

These specimens are typical tıicanus. There is one more, $q$ ad., 13 . IV. 1929, Riuganpo. Its supercilium is yellow, but the color is very faint. It is an intermediate specimen between macronyx and triv'rnus, I believe.

61. Motacilla cinerea caspica (S. G. Gmelin). キセキレイ $2 q q$ ads. 9.-30. IV. 1929. Riuganpo.

$1 \delta$ ad., $2 q q$ ads. 16. VI.-12. VII. 1929. Chrisen.

$2 q \subsetneq$ ads. 26.-27. IX. 1929. Banpo.

1 ad. 11. III. 1930. Quelpart I.

62. Motacilla alba leucopsis Gould. ホホジロセキレイ

7 of $\delta$ ads., 1 ad., 1 juv. 7.-28. IV. 1929. Riuganpo.

1 ơ ad. 14. VI. 1929 . Chōsen.

One young among the above-mentioned specimens is me which has just left its nest. That it left its nest in the last decade of April is rather an early example for that region.

63. Motacilla alba ocularis Swibhoe. タイワンハクセキレイ

3 of $\delta$ ads., 5 $q$ ads. 28. IV.-2. V. 1929. Riuganp"

3 of of ads., 1 \% ad., 4 imms. 17.-27. IX. 1929. Banpo.

64. Motacilla alba lugens Kittlit\%. ハクセキレイ

1 of ad., 1 ad. 11. III. 1930. Quelpart I.

? Motacilla alba amurensis Scebohm.

1 ơ ad. (No. 4012) 4. IV. 1929. Riuganpo.

This specimen is a full adult male and has a black back. Nevertheless, its remex is pale black as in $M$. $a$. ocularis and its chin and throat are also quite black as in ocularis. (The remex of a young bird of $M$. a. lugens is not pale black, but decp brownish black.) This fact wholly coincides with the description of Motacilla amurensis Seebhom (1878Gulf of Abrek, in the See of Japan). But it cannot be determined without 
further investigation whether it is a good subspecies which lits between lugens and ocularis, or only a hybrid between them.

65. Dendronanthus indicus (Gmelin). イワミセキレイ

4 of $\delta$ ads. 9.-17. V. 1929. Riuganpo.

t $\delta$ o ads.. $1 \%$ ad., 1 unsexed ad. 13. VI.- t. VII. 192!!. Chisen. Family ZOSTEROPID瓜. 絋服兒科

66. Zosterops palpebrosa ijimae Kuroda. イイジマメジロ

5 of $\delta$ ads.. 5 $q$ ads. 9.-18. III. 1930. Quelpart I.

67. Zosterops erythropleura erythropleura Swinhoe.

$$
\text { テウセンメジロ }
$$

1 f ad., 1 ad. 16. V. 1929. Riuganpo.

Family CERTHIIDE. 木 走科

68. Certhia familiaris familiaris Linnaeus. キタキバシリ

Synonym: C.f. ernsti Kurodal.

C.f. kawamurai Momiyana.

$6 \delta$ of ads.. $+q q$ ads. 22.-26. X. 1929. Banpo.

Family SITTIDE. 五十售科

69. Sitta europaea amurensis Swinhoe. フムールゴジフカラ

1 ơ ad., 1 q ad. 11.-19. X. 1929. Banpo.

It has hitherto been believed that $S$. curopaea which live in Korea all belong to amurensis But, according to the recent study, those which have been collected in Korea are not amurensis, but hondoensis, and the two specimens collected this time are the first true amurensis collected there. S. e. amurensis do not breed in Korea but merely migrate there rarely in winter.

70. Sitta europaea hondoensis Buturlin. コジフカラ

7 d $\delta$ ads., $3 q q$ ads. 20. VI.-12. VII. 1929. Chōsen.

9 of $\delta$ ads., 1 $q$ ad., 2 jurs. 25. VII.-1. IX. 1929. Nojidō.

3 of $\delta$ ads. 2.-11. X. 1929. Banpo.

Those which breed in Korea are undistinguishable from those in Hondo neither in measurement nor in coloring.

71. Sitta canadensis corea O.-Grant. テウセンゴジフカラ $\pm \delta \delta$ ads., $1 \Varangle$ ad. 30. VII.-29. VIII. 1929. Nojidō. 
Family PARIDA 四十焦科

72. Parus major takahashii Momiyama. テウセンシジフカラ

¿ $\delta$ of ads., 2 $q$ ads. 4.-29. IV. 1929. Riuganpo.

$4 \delta \delta$ ads., $3 q q$ ads., 3 juvs. 15. VI.-9. VII. 192!. Chōsen.

$1 \delta$ ad., 1 q ad., 1 juv. 10. viII.-1. IX. 1929. Nojidō.

$1 \delta$ subad., $2 q$ $q$ subads., 1 unsexed ad. 30. IX.-19. X. 1929. Banpo.

P. major in Korea are easily distinguishable from those in Hondo.

73. Parus major minor T.\&S. シジフカラ

Synonym: $P . m$. quelpartensis Kuroda.

5 of $\delta$ ads., $+q q$ ads. 10.-30. III. 1930. Quelpart I.

Parus major of Quelpart I. are quite undistinguishable from $P . \mathrm{m}$. minor of Hondo in a great number of specimens.

7t. Parus varius varius T. \& S. ヤマガラ

Sinonym: P. v. saisiuensis Kuroda \& Mori.

P. v. koreensis (Kuroda \& Mori)

$1 \delta$ ad., $2 q q$ ads., 3 juvs., 1 unsexed ad.

13. VI.-12. VII. 1929. Chōsen.

$2 \delta \delta$ ads., $2 q q$ ads. 25. II.-3. III. 1930. Moppo.

$5 \delta \delta$ ads., $3 q$ ads. 16..-30. III. 1930. Quelpart I.

7). Parus ater amurensis Buturlin. キタヒガラ

sirnonym: P. a.tyoosenensis Momiyama.

2 of $\delta$ jurs., 1 q ad. 9 viII. 1929 . Chōsen.

$1 \%$ ad., 5juvs. 26 . VII.-29. VIII. 1929. Nojidō.

2 unsexed ad. 19. X. 1929. Banpo.

$1 \%$ ad. 27. XI. 1929 . Kinkwa.

1 ơ ad. 11. I. 1930. Moppo.

All of $P$. ater in Korea and Saghalin belong to this subspecies

76. Parus ater insularis Hellmayr. ヒ カ

Synonym: P. a. takahashii Momiyama.

1 of ad. 16. III. 1930. Quelpart J.

As the result of investigating many specimens, it has become known that $P$. ater in the Quelpart I. are undistinguishable from those in Hondo.

77. Parus palustris hellmayri Bianchi. テウセンコガラ 
1 of ad., $29 q$ ads. 16.-30. VI. 1929. Chisen.

$1 \delta$ ad., 2 imns. 27. XI.-4. XII. 1929. Kinkwa.

$1 f$ ad. 1. III. 1930. Moppo.

P. $p$. hellmayri distribute all over Koren, except the northermmust part. And the results of measurement are follows:

Wing of of 5s-62, \& $958-62$.

Tail of of 51-55, $q$ \%0-54.

7s. Parus palustris jeholicus Kleinschmidt. カンキョウコガラ

9 of $\delta$ ads., 4 $q$ ads., 5 unsexed ad., $1 \mathrm{imm}$.

24. VII.-1. IX. 1!!2!!. Nojidō.

1 unsexed ad. 6. IX. 1929. Sinchō.

The results of measurement of the above-mentioned $9 \& 5$ ads., 4 $q$ ads., 6 unsexed ad. are as follows:

Wing: of of 62-68, $q$ \& 64-65, unsexed 62-69.

Tail: of of 59-65, ๆ $q$ 60-63, unsexed 57-68.

$P$. p. jeholicus is the first collected in Korea. In X. E. Chihli, P. p. jeholicus distributes between the distribution of $P$. p crassirostris and $P$. $p$. hellmayri. In Korea also it distributes in Kankyodo, North Korea, as an intermediate form between crassirostris in Lssuri and hellmayri in Korea.

79. A egithalos caudatus caudatus (Linnaeus). カウライシマェナカ

Synonym: A. c. magna Clark.

$1 \delta$ ad., 2 $q$ ads., 1 unsexed ad., $1 \delta$ juv.

26. VII.-3. IX. 1931). Yojidō.

1 of ad., 1 unsexed ad. 27. I. 1930. Noppo.

The results of measurement of the above-mentioned : $\delta \xi, \geq q q, 1$ unsexed ad. are as follows:

Wing of of 62-64t, + $q 61,61$, unsexed 64,64 .

Tail of 8 88-105, $q$ \% 98, 98, unsexed 91-93.

Of the collection this time, the two specimens above mentioned were collected in South Korea. But A.c. caulatus migrate to south Korea only in winter, I believe.

80. Aegithalos caudatus shimokoriyamae Kuroda.

$$
\text { テウセンェナガ }
$$


") $\delta$ ads., 1 o ad., 1 sulad., 1 unsexed ad.

11. XII. 1929-29. I. 1930. Moppo.

The result of measurement of $9 \delta$ of ads., $1 \%$ ad. above-mentioned are as follows:

Wing of $\delta$ 61-63 (one $=59)$ q 61 .

Tail of of $81-88$ (one $=73)$ $q 7$.

i1. Aegithalos (iuduatus trivirgatus (T.\&S.) $ェ ナ カ$ Synonym: A.c.tarihoe Momiyama.

1 if al. 17. III. 1930. Quelpart I.

The measurement of this specimen is as follows:

Wing 60.5. Tail 73.

Mr. Momiyama has said that A.caudatus in the Quelpart I. hare the following measurement:

Wing si-59.5, tail $71.5-80$.

and have a larger size than those of Hondo. But also in Hondo, there are not a few which have tails above $80 \mathrm{~mm}$. long, and sometimes even a specimen which has a tail $84 \mathrm{~mm}$. long is found there. Even in coloring, there is no distinction between those in Hondo and those in the Quelpart Island.

82. Remiz pendulinus consobrinus (Swinhoe) スキンホーガラ 6 of $\delta$ ads., $2 q \%$ ads. 25. IV.-2. V. 1929. Riuganpo.

\&i3. Regulus regulus japonensis Blakiston. キクイタダキ 4 of $\delta$ ads., 6 $q$ ads., 1 unsexed ad. 16.-21. X. 1929. Banpo.

$1 \%$ ad. 9. I. 1930. Moppo.

$1 q$ ad. 18. III. 1930. Quelpart I.

84. Suthura webbiana fulvicauda Campell. ダルマエナガ

$+\delta \delta$ ads., $5 q q$ ads., 1 unsexed ad.

11. XII. 1929-9. I. 1930. Moppo.

\section{Family LANIIDE. 䴗 科}

85. Lanius sphenocercus sphenocercus Cabanis. オホカラモズ

1 ad. 20. VIII. 1929. Nojidō.

1 ơ ad., 1 q ad. (.-T. IX. 1929. Sanchō.

1 of ad. 18. IX. 1929. Banpo. 
1 of ad.. 1 \& ad. 25. XI.-1. XII. 1929. Kinkwa.

พti. Lanius tigrinus Drapiez. チゴモズ

5 of $\delta$ ads., $: q q$ ads., 2 unsexed ad. 17.-26. V. 1929. Riuganpo.

1 ơ ald. 16. VI. 1929. Chōsen.

‘். Lanius cristatus confusus Stegmann. ウスアカモズ

1 of ad.. 1 \& ad. 11.-21. V. 1929. Riuganpo.

These two specimens coincide with the description of L.c. confusus, with an intermcdiate coloring between $L . c$. cristatus and $L$. c. lucionensis (see the "Tori" Vol. VII. p. 2).

内r. Lanius cristatus lucionensis Linnaeus. シマアカモズ

6 o $\delta$ ad 3 \% $q$ ads. 9.-24. V. 1929. Riuganpo.

1 ơ ad. 2̇i. VII. 1929. Nojidō.

s9. Lanius bucephalus T.\&S. モ $\pi$

$1 \delta$ ad. $1 q$ vix ad. 5. IV. 1!129. Riuganpo.

1 ild. 15. VI. 1929. Chōsen.

1 jov. … X. 1929. Banpo.

$1 \delta$ ad.. $; q q$ ads. 11. XII. 1929-24. II. 1930. Moppo.

$1 \delta$ ad., 1 z subad. 9. III. 1930. Quelpart I.

Family BRACHYPODID压. 蠆 科

90. Micruscelies amaurotis hensoni (Stejneger). エゾヒョドリ

6 of $\delta$ ads. $+q q$ ads. 1s. XII. 1929-26. II. 1930. Moppo

1 of ad. 30. III. 1930. Quelpart I.

The above-mentioned specimens are undistinguishable from those collected in Hokkaid,.

91. Nicroscelis amaurotis amaurotis (Temminck). ヒヨドリ

synonym: M. a. kanrasani Momiyama.

is of $\delta$ ads., 1 ad. 17-30. III. 1930. Quelpart I.

These specimens are undistinguishable from the natives of Hondo.

Family CAMPEPHAGIDA. 山椒喰科

92. Pericrocotus roseus intermedius Clark. テウセンサンセウクヒ 5 of $\delta$ ads.. 5 $\$$ ads., 1 unsexed ad.

24. IV.-16. V. 1929 . Riuganpo. 
Family MUSCICAPIDA. 獕科

13. Tehitrea paradisea incei (Gould). カワリサンコウテウ

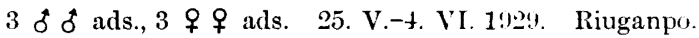

94. Alseonax latirostris latirostris (Raffles). コサメビタキ $6 \delta$ of ads., 2 $q$ ads., 2 unsexed ad. 4.-12. V. 1!29. Riuganpo.

95. Hemichelidon griseisticta griseisticta Swinhoe. エゾビタキ 의 of ads., $2 q q$ ads. 20.-2s. V. 1929. Riuganpo.

96. Hemichelidon sibirica incerta La Touche. ウスサメビタキ Synonym: H. s. opaca Shulpin.

3 of of ads., 6 $q$ ads. 24.-28. V. 1929. Riuganpo.

The specimens collected in Korea, Saghalin and the Kuril Islands have feathers of a pale color than those in Hondo. This fact coincides with the description of incerta La Touche and with description of opaca Shulpin. It is, however, unable to determine whether those in Hondo belong to $H$. s. sibirica or not, as there has never leen found a specimen from the type locality of sibirica.

97. Siphia parva albicilla (Pallas). ヨジロヒタキ 1 f ad., 1 \& ad. 8.-19. 1. 1929. Riuganp's.

요. Siphia mugimaki (Temminck). ムギマキ 2 of $\delta$ ads., 5 \& $q$ ads., 3 imms. 7.-23. V. 19:2!. Riuganpw.

99. 'Zanthopygia nacrissina zanthopygia (Hay). マミジロキビタキ \& $\delta$ of ads., $4 q \%$ ads. 28. IV.-12. V. 1929. Riuganpo.

100. (yanoptila cyanomelana cyanomelana (Temminck). オホルリ 6 of $\delta$ ads., $4 q q$ ads. 24. IV.-7. V. 1929. Riuganpo

1 ơ ad. 29. VII. 1929. Nojidō.

Those which breed in Korea all belong to C.c. cyanomelenu and are undistinguishable from those in Hondo.

101. Cyanoptila cyanomelena intermedia (Weigold).

$$
\text { テウセンオホルリ }
$$

1 of ad. 11. V. 1929. Riuganpo.

This specimen has a conspicuously pale color compared with those in Korea and Hondo. It corresponds to C. c. intermedia. I have already described that $C$. c. intermedia do not breed in Korea. 


\section{Family SYLVIIDE. 笕 科}

102. Acanthopneuste nitidus plumbeitarsus (

$$
\text { ヤナギムシクヒ }
$$

3 of $\delta$ ads., $2 q \%$ ads. 17.-27. V. 1929. Riuganpo.

103. Acanthopneuste tenellipes (Swinhoe). エゾムシクヒ

$3 \delta$ of ads., 4 \& $q$ ads., 1 unsexed arl. 14. V.-3. VI. 1!?!!. Riuganpw.

104. Acanthopneuste borealis borealis (Blasius). コムシクヒ

$10 \delta \delta$ ads., $7 q q$ ads. 17. V. 3. VI. 1!12!!. Riuganpo.

$1 \delta$ ad. 16. IX. 1929. Banpo.

The results of measurement of the 1 s specimens alove-mentioned are as follows :

Wing of $\delta$ 63-69.5. $q$ \% $62.5-1 ; 5.5$.

Tail of of 4t-49. $q$ q $43-4 s$.

105. Acanthopneuste borealis xinthodryas (swinhoe). メボン

$3 q q$ ads. 2-. V.-4. VI. 1929 . Riuganpo.

These specimens are determined to belong to $A$. b. xanthodryns. owing to the fact that they are rich in yellow in the under suriace and have a long 1st primary. Those which breed in Korea belong to this sulspecies. I believe.

106. Acanthopneuste occipitalis coronata (T. \& ..).

$$
\text { センダイムシクヒ }
$$

$7 \delta$ of ads., $2 q q$ ads. 16.-28. IV. 1929. Riuganpu.

107. Phylloscopus inornatus inornatus (Blyth). キマュムシクヒ

$7 \delta$ f ads., $7 q$ q ads. 16. IV.-18. V. 1929. Riuganpo.

108. Phylloscopus proregulus proregulus (Pallas).

$$
\text { カラフトムシクヒ }
$$

5 of $\delta$ ads. 7 \% ads. 5.-17. IV. 1999. Riuganpo.

109. Phylloscopus fuscatus fuscatus (Blyth). ムヂセツカ

$1 \delta$ ad. 26. IV. 1929. Riuganpo.

$1 \delta$ ad. 1. X. 1929. Banpo.

110. Herbivocula schwarzi (Radde). カラフトムヂセツカ

3 of $\delta$ ads., 1 ? ad. 11.-20. V. 1929. Riuganpo.

$1 \uparrow$ ad. 27. VII. 1929. Nojichō. 
According 1 , the collector, they sing "hō-hokekyō," which resembling those of Horrites rantans.

111. Iroreites (antans borealis (Campbell). テウセンウグヒス 9 \&ै ¿ ads. 13. VI.-16. VII. 1929. Chōsen.

1 jur. 2̌r. VIII. 1929. Nojidō.

1 of ad. 1!. X. 1929. Banpo.

Besides, there is one nest (having 3 eggs) which was collected in Nojidio on July s.th, 1!12!!. The collector asserts that it is the nest of one of this sulsweries. But the specimen differs from the others in the point that the engs have large brown blotches on the white ground and the nest is made of many gralss stems. So I can not believe the nest belong to $H$. rantans. I shall wait for the result of further investigation.

112. Horeites cantans takahashii (Momiyama). サイシウウグヒス 6 of of ads.. $+q$ ads. 10.-21. III. 1930. Quelpart I.

H. cantans in Hondo and those in Quelpart I. are easily distinguishable from wach other by the fact that the latter are richer in olive than the former.

113. ITwhliena -ifuameicejs ussuriana (Seebohm).

$$
\text { テウセンヤブサメ }
$$

$2 \delta$ t. als.. $i$ o $q$ als. 24. IV.-3. V. 1929. Riuganpo.

1 \& ad. 9. VII. 1!!2!!. Chösen.

C. squameiceps which live in Korea have a conspicuously pale feather color compared with thuse in Hondo in the specimens of the same season. According to . Mr. Siccholhm, the type specimen of U. squameiceps has dark feather like those in Japan. Therefore, by the fact that the type locality of $U$. squeneiceps is Canton, I regard with some doubt those which live in Korea as belonging to U. U. ussurianu.

114. Locustrlla fissciolata (Gray). エゾセンニウ ¿ all. 4. VI. 1929. Riuganpo.

115. Locustellia certhiola minor David \& Oustalet.

$$
\text { シベリアセンニウ }
$$

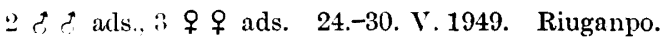


The results of measuremeut of the above-mentioded 5 specimens are as follows:

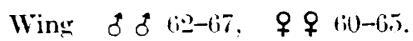

Tail $\delta \delta 5(1-53, q q 45-52$.

116. Locustellia neava lanceolata (Temminck). マキノセン゙ウ

7 of ads., $: \$ q$ ads. 11.-23. V. 1929. Riuganpo.

117. Plıraqumaticola aëdon rufescens Stegmann.

$$
\text { ハシブトオホヨシキリ }
$$

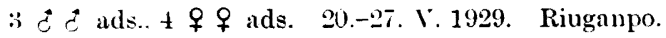

11. Acrephalus stentoreus orientalis (T.\&S.). オホョシキリ

$9 \delta$ ¿ ads.. $\cong$ $q$ ads, 1 unsexed ad.

20. V.-3. VI. 1929. Riuganpo.

119. Acrocephalus bistrigiceps Swinhoe. コョシキリ

$\therefore \delta \dot{d}$ ads.. $2 q q$ ads. 25. V.-1. VI. 1929. Riuganpo.

$1 \delta$ ad., $2 q q$ ads. 1.-13. X. 1929. Banpo.

Fanily TLRDIDE. 桘 科

120. Turdus aurens aureus Holandre. トラツグミ

$3 q q$ ad: 20. IV.-6. V. 1929. Riuganpo.

121. Turdus sibiricus sibiricus Pallas. シベリヤマミジロ

7 of acli.. : $q q$ ads. 16.-20. V. 1929. Riuganpo.

122. Turdus hortulorum Sclater. カラアカハラ

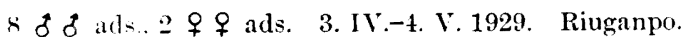

123. Turdu pallidus Gmelin. シロハラ

1 of ad.. 2 $q$ ads. $27 .-30$. IV. 1929. Riuganpo.

1 ind. 17. III. 1929. Quelpart I.

124. Turdus obscurus obscurus Gimelin. マミチヤジナイ

() $\delta \&$ ads., $8 q q$ ads. 11.-19. V. 1929. Riuganpo.

125. Turdus naumanni Temminck. ハチゼウツグミ

2 $\delta \delta$ ad ... $\% q$ ads. 4.-28. IV. 1929. Riuganpo.

$1 \delta$ ad.. 1 \% all. 19.-25. I. 1930. Moppo.

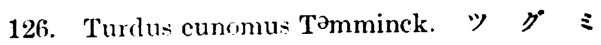

$7 \delta \delta$ ads., $+q q$ ads. 4. IV.-12. V. 1929. Riuganpo.

1 a ad. 12. III. 1930. Quelpart I. 
127. Monticola gularis (Swinhoe). ヒメインヒョ

8 of $\delta$ ads., $3 q q$ ads. 11. 19. V. 1929. Riuganpo.

2 juvs. 26 . ViII. 1929 . Nojidō.

128. Monticola philippensis magna (La Touche). イソヒョドリ

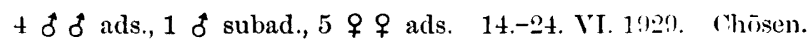

$1 \delta$ ad. 7. I. 1930. Moppo.

$1 \delta$ ad. 13. III. 1930. Quelpart I.

129. Saxicola torquata stejnegeri (Parrot) ノビタキ

3 of $\delta$ ads., $4 q q$ ads. 6.-29. IV. 1929. Riuganpo.

1 ơ ad. 19. VI. 1929. Chōsen.

130. Ianthia cynura cynura (Pallas). ルリビタキ

$2 \delta$ o ads., 2 of $\delta$ subad., $5 q q$ ads. 2.-9. IV. 1!2!9. liuganpo.

$1 \delta \mathrm{imm}$. 19. I. 1930. Moppo.

131. Phoenicurus auroreus auroreus (Pallas). ジヤウビタキ

$2 q q$ ads. 19.-20. VI. 1929 . Chōsen.

1 to ad., 1 ad., 1 juv. 25.-29. VII. 1929. Xi,jidō.

$1 \%$ ad. 24. X. 1929. Banpo.

1 of ad. 30. XI. 1929. Kinkwa.

1 of ad. 7. I. 1930. Moppo.

$P . a$. auroreus breed in the mountain region of the middle :nd the northern part of Korea.

132. Luscinia calliope calliope (Pallas).,$\quad \exists \quad \checkmark$

$1 \delta$ ad., 1 ad. 15.-26. IV. 1929. Riuganpo.

The results of measurement of these speciment are als follows:

Wing of 75, \& 73 Tail of 59, $q$ 5!

133. Luscinia calliope camtschatkensis Gmellin. オホノゴマ

2 of of ads. 12.-17. v. 1929. Riuganpo.

The results of measurement of these specimens are as follows:

Wing 80,80 . Tail 54, 60

According to the recent investigation, $L$. c. calliope has wings $71-77.5$ $\mathrm{mm}$. long and L. e. camtschatkensis wings $77-85 \mathrm{~mm}$. long. It is only in the migration seasons of spring and autumn that specimens which have wings above $78 \mathrm{~mm}$. long are collected in Sagalin, Korea and Manchuria. 
134. Larvivora sibilans Swinhoe. シマゴマ

7 \& $\delta$ ads.. $: q \%$ ads., 1 unsexed ad. 7.-17. V. 1929. Riuganpo.

135. Larvivora cyane (Pallas). $コ \pi$ y

‘ of a ads.. 3 $\%$ ads. 10.-1s. V. 1929. Riuganpo.

Family PRUNELLIDA. 岩 科

136. Prunella montanella (Pallas). ヤマヒバリ

1 d ad. $2-7$. X. 1929. Banpo.

Family TROGLODYTID瓜能 科

137. Troglodytes troglodytes peninsulae (Clark).

$$
\text { テウセンミンサザイ }
$$

s.mon!m: T. t. quelpartis Kuroda \& Mori.

T. t. morii Momiyama.

$1 \delta$ ad.. 1 unsexed ad. 21.-22. X. 1929. Banpo.

$\therefore t ?$ ads.. $: q q$ ads. 1 unsexed ad.

26. XI.-2. XII. $1929 . \quad$ Kinkwa.

ㅇํ $\delta$ ads. $1 q$ ad. 13.-27. XII. 1929. Moppo.

$3 \delta$ o ads.. $5 q q$ ads. 16.-30. III. 1930. Quelpart I.

T. troglonluts in the Quelpart I. and the Dagelet I. are both undistinguishatule from those in Korea, in many specimens.

13:. Cinculus pallasii pallasii Temminck. キタカハガラス

1 juv. ¿. VII. 1929. Chōsen.

1 unsexed ad. ․ XII. 1929. Kinkwa.

Family HIRUNDINIDE 燕 科

139. Hirundo rustica gutturalis Scopoli. ツ ハ メ

7 f $d$ arls. $+q q$ ads. 19. IV.-4. VI. 1929. Riuganpo.

$1 q$ juv. 13. VIJ. 1929. Choōsen.

$1 \delta$ ad. 13. III. 1930. Quelpart I.

1 juv. alove mentioned is pretty rich in red on its under surface.

140. Hirundo rustica tytleri Jerdon. アカハラツパメ

$5 \delta$ के ads., 1 ad. 3. V.-4. VI. 1929. Riuganpo.

3 of $\delta$ ads., $1 q$ ad. 17. IX. 1929. Banpo.

It is worth remarking that in spring $H$.r.tytleri remain in Korca till the beginning of June. 
141. Hirundo daurica nipalensis Hodgson. コシアカツバメ 7 ठै $\delta$ ads., 2 $q$ ads. 13. VI.-14. VII. 192!. Chōsen.

$1 \%$ ads. 25. VII. 1929. Nojidō.

142. Delichon urbica dasypus (Bonaprte). イワッバメ

3 of $\delta$ ads., $4 q q$ ads. 24. VI.-6. VII. 1929. Chōsen.

143. Riparia riparia ijimae (Lönnberg). 七ウドウッバメ

$2 \delta \delta$ ads. 29. V. 1929. Riuganpo.

if $\delta$ of ads, $3 q q$ ads. 13.-20. IX. 1929. Banpo.

Family MICROPODIDA. 丽 燕 科

144. Micropus pacificus pacificus (Latham). アマツバメ

$1 \delta$ ad. 29. V. 1929. Riuganpo.

4 of $\delta$ ads., $3 q q$ ads. 3. VII. 1929. Chōsen.

145. Hirundapus caudacutus caudacutus (Latham).

ハリヨアマツパメ

$1 \%$ ad. 16. V. 1929. Riuganpo.

2 of $\delta$ ads., $2 q q$ ads. 29. VII. 1929. Nojido.

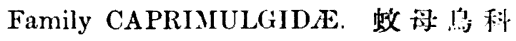

146. Caprimulgus indicus jotaka T. \& S. $\exists$ タ カ

$2 \delta$ of ads., 1 ad. 12.-21. V. 1929. Riugan

Family UPUPIDA. 戴 朌 种

147. Upupa epops saturata Lönnberg. ヤツガシラ

3 \& $\delta$ ads., 2 $q$ ads. 3. IV.-30. V. 1929. Liunanum.

Family CORACIIDE. 佛法仵科

14. Eurystomus orientalis calonyx Sharpe. プツポウンウ

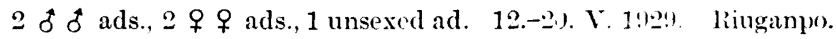

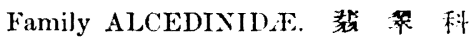

149. Alcedo atthis japonica Bonaparte. カハ七ミ

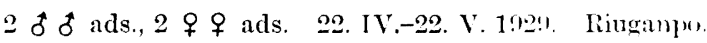

1 ơ imm. 15. VII. 1929. Chösen.

150. Halcyon coromanda major (T. \& S.). フカセウビン

1 ơ ad. 9. VII. 1929. Chōsen.

Family PICIDA. 啄木品科

151. Picus canus jessoensis Stejneger. ヤマゲラ 
Synonym: P. c. griseoviridis (Clark).

$1 \%$ ad., 3 juvs. 9.-10. VII. 1929. Chösen.

5 of $\delta$ juvs. 1.-10. VIII. 1929. Nojidō.

2 of $\delta$ ads., 1 q ad. 3.-11. XI. 1929. Banp"

As the result of investigating many specimens. it hats hecomu known that there is no difference between $P$. canus in Korea : and $P$. c. jessoensis in Hokkaido either in coloring or in measurement.

152. Dryobates major japonicus (Steclolım). エソீアカゲラ

$3 \delta \delta$ ads., $2 q q$ ads., 2 juvs. 24. VII.-2. IX. 1999. Nojidī.

3 of $\delta$ ads. 24. X.-17. XI. 1929. Banpo.

The results of measurement of $6 \delta \delta$ ads. and $\geq q$ ads. alowe-mentioned are as follows:

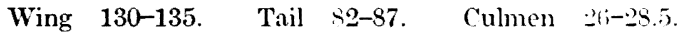

D. major which breed in the mountains of the northern pirt of Kore: and migrate to the middle part in winter have the same coloring and measurement as those in Hokkaido.

153. Dryobates major hondoensis Kuroda. アカゲラ

Synonym: D. m. seoulensis Kuroda \& Mori.

1 đ̊ ad., 1 juv. 6.-9. VII. 1929. Chōsen.

$1 \delta$ ad., 1 \& ad. 25.-29. XI. 1929. Kinkwa.

18 ad. 28. II. 1930. Moppo.

D. major which live in the middle and the southern part of Kore: differ from those which breed in the mountain region of Koreal, and hiv ve the same coloring and measurement as those in Hondo.

154. Dryobates leucotos uralensis (Malherbe).

$$
\text { シベリアオホアカダラ }
$$

$6 \delta \delta$ ads., $2 q q$ ads., 4 juvs. 24. VII.-22. VIII. 19?!. Nojidō.

$1 \delta$ ad., $2 q q$ ads. 3.-17. XI. 1929. Banpo.

I have already described in the "Tori," Vol. VII. p. 1 , that $D$. leucotos which live in the mountains in Kankyohokudo, Korea, are identical with $D$. l. uralensis which live in the Ural region.

155. Dryobates leucotos coreensis Clark. テウセンオホアカゲラ

3 ơ $\delta$ ads., 1 \% ad. 6.-16. VII. 1929. Chōs:n 
D. l. coreensis distributes all over Korea, except Kankyohokudo.

15fi. Dryobates leucotos quelpartensis Kuroda \& Mori.

サイシウオホアカゲラ

万ठ $\delta$ ads., $5 q q$ ads. 16.-26. III. 1929. Quelpart I.

157. Dryobates minor nojidoensis Yamashina. テウセンコアカゲラ $4 \delta \delta$ ads., 5 $q$ ads., $1 \delta$ juv., 1 subad.

30. VIII.-1. IX. 1929. Nojidō.

(See the "Tori," Vol. VI, p. 254.)

15\%. Dryolates hyperythrus subrufinus (Cab. \& Heine).

$$
\text { チヤバラアカダラ }
$$

2 of ads., 1 \& ad. 12. V.-3. VI. 1929. Riuganpo.

These are the first specimens collected in Korea. (See the "Tori," Vol. vi, p. 16.)

159. Dryobates nanus doerriesi (Hargitt). フムールコゲラ

1 ơ ad., 1 \& ad. 9. VII. 1929. Chōsen.

$1 q$ ad. 26. VII. 1929. Nojidō.

$2 q q$ ads. 16.-28. X. 1929. Banpo.

1 of ad. ㄴ. II. 1930. Moppo.

160. Dryobates kizuki acutirostris Yamashina. ハシナガコダラ

$2 \delta$ of ads.. $2 q q$ ads., 5 juvs.

13. VI.-4. VII. 1929. Kongōsan, Chōsen.

(See the "Tori," Vol. VII, p. 111.)

161. Dryobates kizuki nippon (Kuroda). コ

S Srnonym: D. k. siragiensis Momiyama.

$1 \delta$ ad., $\supseteq q q$ ads. 24.-27. II. 1930. Moppo.

These specimens are quite undistinguishable from $D . k$. nippon of Hondo like the tỵe specimens of $D$. $k$. siragiensis collected in Kōryo, Keikido near Keijō.

162. Picoides tridactylus kurodai Yamashina. テウセンミュビゲラ

2 ठै $\delta$ ads., 3 $q$ ads. 19. VIII.-2. IX. 1929. Nojidō.

(See the "Tori," Vol. VI, p. 255.)

163. Iryocopus martius martius (Linnaeus). クマゲラ

Sinonym: D. m. morii Kuroda. 
$2 \delta$ d ads., $s q q$ ads. 24. VII.-19. VIII. 1929. Nojidō.

The results of measurement of the $10 \& q$ above mentioned are as follows:

\begin{tabular}{|c|c|c|}
\hline Wing & of ช $233-247$ & $q q 233-250$. \\
\hline Tail & ठิ ฮิ 155-162 & q $155-174$. \\
\hline Culmen & ठ઼ ฮे 58-60 & 우 53-59. \\
\hline
\end{tabular}

164. Jynx torquilla intermedia Stegmann. シベリケアリスヒ

6 of of ads., 3 $\%$ ads. S. IV.-2. V. 1929. Riuganpo.

The results of measurement of the nine specimens above mentioned are as follows:

\begin{tabular}{|c|c|c|}
\hline Wing & ơ ठे 81-85 & 우 $81-83$. \\
\hline Tail & $\delta \delta 64-73$ & $q q 68-70$. \\
\hline Culmen & ðð ठ 13.5-14 & 우 우 13.5-16. \\
\hline
\end{tabular}

165. Cuculus optatus optatus Gould. ツツドリ

5 of $\delta$ ads., $5 q q$ ads. 8. V.-1. VI. 1929. Riuganpo.

166. Cuculus poliocephalus poliocephalus Latham. ホトトギス

$1 \delta$ ad. 24. V. 1929. Riuganpo.

167. Cuculus micropterus micropterus Gould. セグロカクコウ

1 of ad. 24. V. 1929. Riuganpo.

168. Hierococcyx fugax hyperythrus (Gould). ジウイチ

$2 \delta \delta$ ads., $3 q \%$ ads. 21.-25. V. 1929. Riuganpo.

Family STRIGIDÆ. 泉 皌 科

169. Bubo bubo tenuipes Clark. ワシミミッ゙ク

$1 \delta$ ad., $1 \Varangle$ ad. 12. I.-12. II. 1930. Moppo.

170. Otus bakkamoena ussuriensis (Buturlin).

サメイロオホコノハッ゙ク

$8 \delta \delta$ ads., $9 q q$ ads. 15.-27. X. 1929. Banpo.

1 unsexed ad. 8. II. 1930. Moppo.

The results of measurement of the specimens above mentioned are as follows:
Wing of $\delta$ 162-171
우 $176-189$.
Tail of $\delta$ 70-84
우 우 82-89. 
A great number of this subspecies pass Korea in spring and autumn and only few pass the winter there.

171. Otus scops stictonotus (Sharpe). テウセンコノハッ゙ク

$2 \delta \delta$ ads., $3 q q$ ads. 29. IV.-12. V. 1929. Riuganpo.

1 ơ ad. ํ. VIII. 1929. Nōjidō.

1 of ad. 5. X. 1929. Banpo.

The measurement of $4 \delta \delta$ and $3 q q$ above mentioned is as follows:

Wing of of 137-147 $q$ क 143-147.

Tail of of 59-15s $q$ क $63-67$.

Those which breed in North Korea belong no doubt to this subspecies. But, sometimes, O. s. japranicus are collected in the middle part of Korea, but they are not found in the collection of this time. It is not clear is yet what subspecies those which breed in the middle and the southern part of Korea belong to.

172. Asio otus outs (Linnaeus). トラフッ゙ク

1 f ad. 4. IV. 1929. Riuganpo.

$1 \delta$ ad., $3 q q$ ads. 19.-22. X. 1929. Banpo.

173. Asio flammeus flammeus (Pontoppidan). コミミッ゙ク

$1 \%$ ad. 14. IV. 1929. Riuganpo.

1 of ad.. 1 \& ad. 12. I.-12. II. 1930. Moppo.

174. Ninox scutulata ussuriensis Buturlin. テウセンアアパック

$3 q q$ ads. s.-21. V. 1929. Riuganpo.

1 of ad. 16. X. 1929. Banpo.

The measurement of 4 specimens above mentioned is as follows:

Wing of 233 \% $229-232$.

Tail of 128 $+q 117-121$.

Ninox scutulata ussuriensis merely pass Korea and do not breed there. Those which breed in Korea belong to N. s. scutulata. But the latter were not collected this time.

\section{Family FALCONID后，热䍃 科}

175. Falco peregrinus calidus Latham. ヘャブサ 2 imms. 30. IX.-4. X. 1929. Banpo.

176. Falco subbuteo subbuteo Linnaeus. チゴハヤブサ 
$+q$ ads. 11.-2․ V. 1929. Riuganpo.

177. Falco columbarius insignis (Clark). コチョウゲンボウ

$1 \%$ ad. 18. X. 1929. Banpo.

1 ơ juv. ֵ.. 1. 1930. Chitō.

1て. Falco vespertinus amurensis Radde. アカシチョウゲンポウ

¿ juvs. 6. IX. 1929. sinchō.

1 jur. 11. X. 1929. Banpo.

179. Falco tinnunculus japonensis Ticehurst. チョウゲンボウ

1 d ad. 29. XI. 1929. Kinkwa.

2 \& $q$ ads. 24. XII. 1929. Noppo.

The measurement of the 3 specimens above mentioned is as follows:

Wing $\delta 244 \quad q \% 251-261$.

Tail of 174 \& $17,5-1$ s3.

180. Falco tinnunculus tinnunculus Linnaeus.

$$
\text { テウセンチョウゲンボウ }
$$

ๆ ad. 21. X. 1929. Banpo.

The measurement of this specimen is as follows:

Wing 266. Tail 189 .

This specimen is regarded as belonging to $F$. $t$. tinnunculus owing to its pale feather color. F.t. tinnunculus rarely migrate to Korea in winter.

1s1. Aquila chrysaëtos japonica Severtzow. イメワシ

1 juv. 2. XII. 1929. Kinkwa.

182. Buteo ferox hemilasius T.\& $\&$ オホノスリ

$1 \delta$ ad., 2 $q$ ads. 17. I.-17. II. 1929. Moppo.

The measurement of the 3 specimens above mentioned is as follows:

$\begin{array}{lll}\text { Wing } & \delta 429 & q \\ \text { Ex. culmen. } & \delta 26 & \text { o } 2626,27.5 .\end{array}$

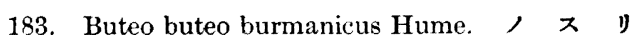

$2 \delta \delta$ ads., $1 q$ ad. 26.-28. XI. 1929. Kinkwa.

1 of ad., 2 $\&$ ads., 29. I.-19. II. 1930. Moppo.

1 \& ad. 30. III. 1930. Quelpart I.

184. Circus spilonotus Kaup. シベリアチウヒ

$1 \delta$ ad. 21. IV. 1929. Riuganpo. 
$1 \nmid$ ad. 24. VIII. 1929. Nojidō.

15.5. Circus aeruginosus aeruginosus (Linnaeus). チ ウ ヒ

$3 q \%$ ads. 13. IX.-12. X. 1929. Banpo.

186. Circus melanoleucus (Forster). マダラチウヒ

1 of ad., 3 jurs. 25. VII.-29. VIII. 1929. Nojidō.

$1 \delta$ ad. 15. JX. 1929. Banpo.

187. Circus cyaneus cyaneus (Linnacus). ハイイロチウヒ

1 ơ imm. 7. XI. 1929. Banpo.

185. Accipiter nisus nisosimilis (Tickell). ハイタカ

$1 \%$ ad. 10. IV. 1929. Riuganpo.

1 ad. 24. VIII. 1929. Nojidō.

$1 q$ juv. 10. X. 1929. Banpo.

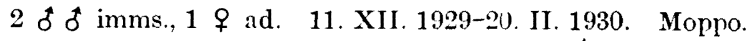

189. Accipiter virgatus gularis (T.\& S.). $\% ~ ₹$

$1 \%$ ad. 14. V. 1929. Riuganpo.

$1 q$ juv. 6. IX. 1929. Nojidō.

190. Milvus migrans lineatus (Gray). $\vdash ヒ ゙$

$2 q q$ ads. 12. I.-19. II. 1930. Moppo.

191. Haliaeëtus pelagicus pelagicus (Pallas). オホワシ

1 of juv. 24. XII. 1929. Moppo

1 juv. 22. III. 1930. Quelpart I.

192. Pandion haliaëtus haliaëtus (Linnaeus). ミ サ ゴ

1 ad., 1 unsexed ad. 2.-25. X. 1929. Banpo.

Family PLEGADID瓜朱 科

193. Platalea minor T. \& S. クロッラヘラサギ

1 of ad. 23. IV. 1929. Riuganpo.

Family ARDEID瓜. 科

194. Ardea cinerea rectirostris Gould. $ア ヌ サ キ ゙$

1 of ad.. 1 ad. 9.-20. IV. 1929. Riuganpo.

2 juvs. 24.-29. IX. 1929. Banpo.

1 đ̊ ad. 23. I. 1930. Chitō.

195. Ardea purpurea manillensis Meyen. ムラサキサギ

5 jurs. 24. IX.-IX. 1929. Banpo. 
196. Egretta alba alba (Linnaeus). ダイサギ

1 ad. 31. I. 1930. Moppo.

Measurement: Wing 410 , culmen 113.

197. Egretta alba modesta (Gray). チウダイサギ［コモ、ジロ ]

1 o ad. 22. IV. 1929. Riuganpo.

Measurement: Wing 350 , culmen 105.

198. Hemigarzetta eulophotes (Swinhoe). カラシラサギ

1 of ad. 30. IV. 1929. Riuganpo.

199. Demiegretta sacra ringeri Stejneger. クロサギ 1 of ad. 22. III. 1930. Quelpart I.

Measurement: Wing 303. culmen 89.

200. Ixobrychus eurhythmus (Swinhoe). オホョシゴイ

3 of $\delta$ ads.. $3 q q$ ads. $\because 0 .-24$. V. 1929. Riuganpo.

Family ANATIDE. 陮鴊 科

201. (ygnopsis cyonoid (Linnaeus). サカッラガン

1 ơ ad.. 1 \% ad. 7.-10. IV. 1929. Riuganpo.

$1 \delta$ ad., 1 q ad. 29. IX. 1929. Banpo.

202. Anser albifrons albifrons (Scopoli). $\checkmark$ カ $ン$

$2 \delta$ od, 1 \& ad. 4.-15. IV. 1!99. Riuganpo.

$1 \delta$ ad., 1 \% ad.. 2 imms. 13. XII. 1929-10. II. 1930. Moppo.

203. Anser fabalis serrirustris Swinhoe. ヒシクヒ

1 of ad. 10. X. 1929. Banpo.

1 of ad. 12. II. 1930. Moppo.

The measurement of the specimens ahove mentioned is as follows:

Wing 45.5-46;s, culmen 63-71.

They belong, no doubt, to serrirostris, but the following specimens certainly an intermediate form between serrir stris and curtus.

1 imm. 12. X. 1929. Banpo.

Measurement: Wing 420, culmen 62 .

204. Anser fabalis curtus Lönnberg. ヒメヒシクヒ

$1 \delta$ ad., 1 \& jur., $2 q 9$ imms. 20. IX.-12. X. 1923. Banpo.

The measurement of the 4 specimens above mentioned is as follows: 


\begin{tabular}{|c|c|}
\hline & Wing \\
\hline $1 \delta \mathrm{ad}$. & $4: 1$ \\
\hline $1 \delta$ juv. & $41 \mathrm{~s}$ \\
\hline $\mathrm{imm}$. & $+13-425$ \\
\hline
\end{tabular}

205. Branta bernicla nigricans (Lawrence). コグガン

$1 \delta$ ad., 1 ad. 11. I. 1929. Moppo.

206. Tadorna tadorna (Linnaeus). ツクシガモ

2 of of ads. 17. IV. 1929. Riuganio.

207. Anas platyrhycha platyrhyncha Linnaeus. $マ カ モ$

1 of ad. 4. IV. 1!209. Riuganpo.

1 of ad., 1 \& ad. 8.-12. X. 192!. Banpo.

208. Anas superciliosa zonorhyncha swinhoe. カルガモ

1 \& ad. 6. IV. 1!)! Riuganpo.

$1 \%$ ad. 13. VII. 1929. Chōsen.

1 of ad. 10. X. 190!!. Banpo.

1 of ad. 27. XII. 1929. MIoly

2 juv. (downy). ๑5. Vi. 19??. Chōsen.

209. Querquedula crecca crecca (Linnaeus). コ ガ

$1 \delta$ ad., 2 $q$ ads. 11.-21. IV. 19:9. Riuganpo.

$1 \delta$ ad., 1 of ad. 16. IX. 1929. Banjo.

210. Querquedula querquedula (Linnaeua). シマアヂ

1 of ad., 1 ad. 17.-20. IV. 1929. Riuganpo.

211. Mareca penelopu (Linnaeus). ヒドリガモ

$1 \delta$ ad. 22. IV. 1929. Riuganpo.

212. Eunetta falcata (Georwi). ヨシガモ

1 \& ad. 22. IV. 1929. Riuganpo.

1 of imm., 1 q imm. 24. IX. 19:9. Banpo.

213. Spatula clypeata (Limnaeus). ハシビロガモ

$q$ ad. 29. IV. 1929. Riuganpo.

$1 \delta$ imm., 1 q ad. 12.-23. X. 1929. Banpo.

214. Aix galericulata (Iinnaeus). ヨシドリ

3 of $\delta$ ads., $1 q$ ad. 5.-14. IV. 1929. Riuganpo.

215. Nyroca fuligula (Linnaeus). キンクロハジロ 
$1 \delta$ imm., $1 q$ ad., $2 q q$ imms. 14. X.-12. XI. 1929. Banpo.

216. Nyroca marila mariloides (Vigors). スズガモ

$1 \delta$ imm., 1 ad. 12. XI. 1929. Banju.

217. Bucephala clangula clangula (Linnaeus). ホホジロガモ

$1 q$ ad. 2S. III. 1930. Quelpart I.

218. Melanitta fusea stejnegeri (Ridgway). ビロウドキンクロ

1 to ad. 24. X. 1929. Banpo.

219. Melanitta nigra americana (Swainson). クロガモ

2 of of ads. 24. X. 1929. Banpo.

220. Histrionicus histrionicus pacificus Brooks. シノリガモ

4 of of ads. 1 \% ad. 24. X. 1929. Banpo.

221. Mergus merganser merganser Linnaeus. カハアイサ

$1 q$ ad. $2 \subseteq$. XI. 1929. Kinkwa.

$1 \%$ ad. 1s. XII. 1929. Moppo.

The measurement of $2 q q$ ads. above mentioned is as follows:

Wing 260-205. Culmen 52-56.

222. Mergellus albellus (Linnaeus). ミコアイサ

$1 \delta$ imm., $4 q q$ ads. 9.-15. IV. 1929. Riuganpo.

Family PHALACROCORACIDA. 擄 科

223. Phalacrocorax capillatus (T. \& S.). ウ ミウ

உ $\subsetneq$ imms. 2.--90. X. 1929. Banpo.

$1 \delta$ ad., $1 \subsetneq$ ad., 1 unsexed ad. 13.-22. III. 1930. Quelpart I.

224. Phalacrocorax pelagicus pelagicus Pallas. ヒメ.ウ

1 of imm., 1 ad., 1 imm. 13.-22. III. 1930. Quelpart I. Family PODICIPIDE. 鷿 䝠 科

225. Podiceps auritus (Linnaeus). ミミカイツブリ

ad. 6. X. 1929 . Banpo.

Family COLUMBIDA. 鸠 鸽 科

226. Columba rupestris rupestris Pallas. カウライバト

2 ठิ $\delta$ ads., $3 q q$ ads. 15.-18. IV. 1909. Riuganpo.

$1 \%$ ad. collected on April 18th has an egg in its oviduct, whose eggshell has been already formed. The measurement of this egg is $35 \times 26$ $\mathrm{mm}$. 
227. Streptopelia orientalis orientalis (Latham). キジハト

3 of $\delta$ ads., 12-16. IV. 1929. Riuganpo.

$1 \delta$ imm., 1 \& ad. 15-VII. 1929. Ohōsen.

$1 \delta$ ad. 24. II. 1930. Moppo.

228. Streptopelia decaocto decaocto (Frivalszky). シラコバト

1 unsexed ad. VIII. 1929. Banpo.

Family CHARADIIDÆ. 千鸟科

229. Charadrius dubius curonicus Gmelin. コチドリ

$1 \delta$ ad., $3 q q$ ads., 1 unsexed ad. 6.-12. IV. 1929. Riuganpo.

230. Charadrius placidus Gray. イカルチドリ

$4 \delta \delta$ ads., 1 \% ad. 30. XI.-4. XII. 1929. Kinkwa.

231. Charadrius mongolus mongolus Pallas. メダイチドリ

$1 q$ ad. S. V. 1929. Riuganpo.

$3 \delta$ of ads, 2 $q$ ads. 17.-19. IX. 1929. Banpo.

232. Pluvialis apricarius fulvus (Gmelin). ムナグロ

1 unsexed ad. 14. IV. 1929. Riuganpo.

$2 \delta$ of ads., 2 $q$ ads. 17.-18. IX. 1929. Banpo.

233. Squatarola squatarola hypomelaena (Pallas). ダイゼン

$3 q q$ ads. 15.-29. IV. 1929. Riuganpo.

1 \& ad., $2 \&$ ads. 17.-26. IX. 1929. Banpo.

234. Vanellus vanellus (Linnaeus). タ

1 ơ imm., 1 o ad. 13. X-1. XI. 1929. Banpo.

235. Hacmatopus ostralegus osculans Swinhoe. ミヤコドリ

1 of ad. 23. IV. 1929. Riuganpo.

$1 \&$ ad. 7. II. 1930 . Moppo.

2 of of ads. 15. II. 1930. Chitō.

236. Arenaria interpres interpres (Linnaeus). キョウジョシギ

$1 \delta$ imm., $2 q q$ ads. 19.-22. IX. 1929. Banpo.

Family SCOLOPACID瓜私

237. Erolia alpina sakhalina (Vieillot). ハマシギ

$3 \delta \delta$ ads., $2 q q$ ads. 25. IV. 1929. Riuganpo.

$2 \delta \delta$ ads., $3 q q$ ads. 16.-19. IX. 1929. Banpo.

$1 \%$ ad. 3. I. 1930. Moppo. 
Among the above specimens $q$ ad. (19. IX. 1929, Banpo) is a full albino.

238. Pisobia minuta ruficollis (Pallas). トウネン

3 ठ $\delta$ ads., $2 q q$ ads. 25. IV.-13. V. 1929. Riuganpo.

239. Pisobia minutilla subminuta (Middendorff). ヒパリシキ

3 of $\delta$ ads., 2 $q$ ads. 9.-19. V. 1929. Riuganpo.

240. Pisobia maculata (Vieillot). フメリカウッララジ

1 f imm., $2 q q$ imms. 19.-25. IX. 1929. Banpo.

About the specimen, $\$ \mathrm{imm} ., 25$. IX. 1929, Banpo, among the abovementioned specimens, I have not described in the "Tori," Vol. VI, p. 252.

241. Pisobia acuminata (Horsfield). ウッ゙ラシギ

$+q \subsetneq$ ads. 19.-25. V. 1929. Riuganpo.

242. Calidris tenuirostris (Horsfield).

$1 \delta$ imm., 1 ad., 1 imm. 19.-23. IX. 1929. Banpo.

243. Crocethia alba (Pallas). ミュビシギ

I of ads., $3 q q$ ads. 13. IX. 1929. Banpo.

24. Limicola falcinellus sibirica Dresser. キリアイ

$1 q$ ad. 16. LX. 1929. Banpo.

245. Glottis nebularius (Gunnerus). アアアシシギ

3 ठ $\delta$ ads., 1 unsexed ad. 2.-14. V. 1929. Riuganpo.

$1 \delta$ ad., $3 q q$ ads., $1 q \mathrm{imm}$. 16. IX.-9. X. 1999. Banpo.

246. Tringa erythropus (Pallas). ツルシギ

1 \& ad. 11. IV. 1929. Riuganpo.

3 \% imms. 21. IX.-18. X. 1929. Banpo.

247. Tringa totanus eurhinus (Oberholser). アカアシシギ

3 of $\delta$ imms., 1 9 ad., 1 imm. 17.-19. IX. 1929. Banpo.

245. Tringa ochropus Linnaeus. クサシギ

$1 \delta$ ad. 1. X. 1929. Banpo.

1 ad. 27. XII. 1929. Moppo.

249. Tringa glareola Linnaeus. タカブシギ

4 of $\delta$ ads., 1 9 ad. 24. IV.-10. V. 1929. Riuganpo.

$1 q$ ad. 9. X. 1929. Banpo.

250. Tringa incana brevipes (Vieillot). キアシシギ 
1 ad. 4. X. 1929. Banpo.

251. Tringa hypoleucos Linnacus. インシギ

1 imm. 19. IX. 1!29. Banpo.

25. Lobipes lobatus (Linnaeus). アカェリヒレアシシギ

$2 \delta$ d ads., : $q$ q ads. 15.-17. IX. 1929. Banpo.

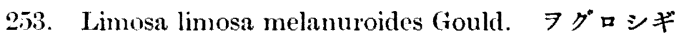

3 of of ats.. 2 $\%$ ads. 13. IX. 19.9. Banpo.

254. Limosa lapponica baueri Naumann. オホソリハシシギ

i) of of imms. 17. IX. 1929. Banpo.

255. Numenius arquata orientalis Brehm. ダイシャクシギ

2 \& $\delta$ ads., 1 unsexed ad. 17. I.-14. II. 1930. Moppo.

256. Sumenius cyanopus Vieillot. ホウロクシギ

1 f ad., 1 \& ad. 14.-19. V. 19.9!. Riuganpo.

257. Numenius phaeopus variegatus (Scopoli). チウシャクシギ

3 of of ads., 1 \& ad. 14. IV.-2. V. 1929. Riuganpo.

258. Numenius minutus Gould. コシャクシギ

$1 \delta$ ad., 1 ad. 29.-30. IV. 1929. Riuganpo.

The measurement of $\delta q$ above mentioned is as follows:

Wing of $176 \quad q 185$, culmen $\delta t 2 q 4 i$.

259. Scolopax rusticola rusticola Linnaeus. ヤマシギ

1 of ad. 9. IV. 1929. Riuganpo.

The measurement of this specimen is, wing 185, culmen 72 .

260. Capella gallinago raddei (Buturlin). 夕 シ $\neq$

3 of $\delta$ ads., 1 o ad. 12.-18. IV. 1929. Riuganpo.

$1 q$ ad. 14. III. 1930. Quelpart I.

261. Capella stenura (Bonaparte). ハリ

$1 \delta$ ad., $4 q q$ ads. 10.-11. V. 1929. Riuganpo.

$1 q$ ad. 6. VIII. 1929. Nijidō.

Family LARID瓜. 跑

262. Sterna hirundo longipennis Nordmann. アジサシ

2 \& $\delta$ jurs., $1 q$ juv. 25. IX. 1929. Banpo.

263. Larus argentatus vegae Palmén. 七グロカモメ

1 unsexed ad., 2 subad., 1 imm. 13. III. 1930. Quelpart I. 
264. Larus canus major Middendorff. カ $モ$ メ

$1 \%$ ad. 19. II. 1930. Moppo.

265. Larus crassirostris Vieillot. ウミネコ

1 unsexed ad. 14. IV. 1929. Riuganpo.

966. Larus ridibundus sibiricus Buturlin. ユリカモメ

$1 \delta$ ad., $3 q q$ ads., $2 q q$ 2nd yoars. 15.-27, IX, 1929 Banpo

I have described in the "Tori," Vol. VI. p. 25i3, that L. r. ridibundus live in Korea, too. But according to the recent study. it is wrong to classify L. ridibundus which come to Japan into two subspecies, the difference of size, which has hitherto been regarded as the main point of the classification. being only an individual variation. Further investigation, however. is required to determine which name we can rightly apply to them, L. r. ridibundus or L. r. sibiricus.

\section{Family BALEARICIDA. 鹤 科}

267. Grus monachus Temminck. ナベッ゙ル

$3 q$ ads. $99 q$ imms. 15. I.-11. II. 1930. Jopm.

265. Grus vipio Pallas. マナッ゙ル

1 \& imm. 29. I. 1930. Moppo.

Family RALLIDE. 秋 准 科

269. Porzana pusilla pusilla (Pallas). ヒヌクヒナ

$1 q$ ad. 30. V. 1929. Riuganpo.

$1 \delta$ ad. 16. X. 1929. Banpo.

270. Porzana fusca erythrothorax (T.\&S.). ヒクヒナ

$1 \delta$ ad. 13. VII. 1929. Chōsen.

2-1. Porzana paykullii (Ljungh). カウライヒクヒナ

o ad. 26. V. 1929. Riuganpo.

272. Gallicrex cinerea (Gmelin). ツルクヒナ

2 of of ads. 31. V.-3. VI. 1929. Riuganpo.

2 ơ ठิ ads., 1 q ad. 25.-29. VI. 1929. Chõsen.

273. Fulica atra atra Linnaeus. オホバン

2 \& $\delta$ ads., 1 ad. 15.-20. IX. 1929. Banpo. 


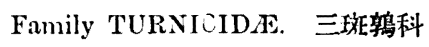

274. Turnix tanki blanfordi Blyth. テウセンミフウッ゙

$\because$ ๆ alls. 23.-24. V. 1929 . Riuganpo.

Family TETRAONIDE. 松 积 科

ㄲ... Lyrurus tetrix ussuriensis (Kohte). クロライテウ

synonym: L.t. koreensis Mori.

t $\delta$ ot ads.. $3 q q$ ads., $+q q$ imms. 11.-26. VIII. 1929. Nōjidō.

ㄱi.i. Tetrastes bonasia coreensis Kuroda \& Mori.

$$
\text { テウセンェゾライテウ }
$$

1 ơ ad., 3 jurs. 6.-9. vil. 1929. Chōsen.

1 of ad., 1 juv. 25. VIII-1. IX. 1929. Xöjidō.

Family PHASIANIDE. 稓 科

פテて. Coturnix coturnix japonica T.\&S. ウッ゙ ラ

$1 \delta$ ad., 1 q ad. 4.-11. v. 1929. Riuganpo.

2 of $\delta$ ads. 15.-18. VIII. 1929. Nōjidō.

$1 \delta$ add., 1 q ad. 22. IX.-22. X. 1929. Banpo.

1 a al. 17. I. 1930. Moppo.

27S. Phasianus colchicus karpowi Buturlin. カウライキジ

Srnonym: P. c. quelyartis Momiyama.

$2 \delta \delta$ ads., $2 q q$ ads. 1s. XII. 1929-31. I. 1930. Moppo.

$2 \delta \delta$ ads., 1 q ad. 9-30. III. 1930. Quelpart I.

27!). Phasianus colchicus pallasi Rothschild. ホクマンキジ

$1 q$ ad.. 6 juvs. 27. VII-11. VIII. 1929. Níjicto.

;) of of ads.. 1 \% ad., 1 imm. 27. IX-29. X. 1929. Banpu. 